\title{
Professor Trefor Jenkins: A tribute
}

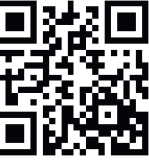

Trefor Jenkins is a true Welshman, born in Wales at Merthyr Tydfil on 24 July, 1932, in a Glamorgan coal mining valley and within a coal mining family. $\mathrm{He}$ lived with his extended family and went to school at the local junior school and on to the grammar school. He then moved to London to study medicine at King's College, University of London, and Westminster Hospital. After graduating in 1956, he took a position in the Royal Army Medical Corps, then one with the South Wales Regional Hospital Board. He emigrated to Zimbabwe (then Southern Rhodesia) in 1960 to take up a post as medical officer at the Wankie Colliery Hospital. There he first came across sickle cell anaemia, which stimulated his life-long interest in both haematology and genetics. With a young family, he moved to South Africa to work firstly in a Durban hospital and then in Johannesburg at the University of the Witwatersrand Medical School (where he says he found his academic home), with Professor Philip Tobias, in Anatomy.

In 1965 he was appointed as a pathologist at the South African Institute for Medical Research (SAIMR). The transition to Human Genetics came in 1969 when he took up the positions of head of the Human Sero-Genetics Unit at the SAIMR and part-time lecturer in Human Genetics in the Department of Anatomy. He was awarded an MD in 1973 and became a specialist pathologist (haematological), registered with the South African Medical and Dental Council (SAMDC), the same year. In 1975 the new chair of Human Genetics was created at the University of the Witwatersrand and he became the first incumbent. He retired in 1998 and subsequently became an Emeritus Professor and an Honorary Professorial Research Fellow in the Division of Human Genetics. During his retirement, he took an active interest in medical ethics and was appointed to a part-time post in the discipline at the medical school. He also played a major role in the establishment of the Institute for Human Evolution and acted as interim director from 2004 to 2009.

Professor Jenkins was a prolific writer; during his academic career, he published many papers, in peer-reviewed journals, as well as book chapters and books. Due to his extensive research record, he was awarded a Medical Research Council unit, with funding for three successive five-year periods from 1977 to 1993 . He developed an enormously successful Department of Human Genetics, which is still the largest in the country, expanding the staff, taking higher degree students and covering many aspects of the field from the serogenetic, cytogenetic, clinical, epidemiological and psychosocial to the ethical, molecular and population genetics aspects. He also extended the laboratory, educational and clinical genetic services, and kept up to date with international developments in the field.

His educational interests led him to increase the contribution of genetics to the undergraduate medical student curriculum, while his enthusiasm for research led him to encourage his staff, colleagues and clinicians to pursue higher degrees in human genetics. As a result, he supervised many successful MSc and PhD candidates. He was awarded honorary degrees by the universities of Cape Town (DSc), Witwatersrand (MD) and South Wales (an honorary doctorate), and many other academic distinctions and prizes.

In addition to his academic work, Professor Jenkins was involved in many community activities, such as the Southern African Inherited Disorders Association, as well as local and international learned societies, including the American Society of Human Genetics, the International Association of Human Biologists, the Galton Institute in London and the Institute for the Study of Man in Africa. He was also deeply concerned with the injustices of apartheid and human rights issues and, together with Professors Philip Tobias and Frances Ames (from the University of Cape Town), challenged the unethical behaviour of the doctors who treated Steve Biko by ensuring that the SAMDC mounted a full investigation. Further, in 1998, he was awarded the prestigious Benjamin Pogrund Medal for advancing the cause of non-racialism in the University of the Witwatersrand.

This festschrift was conceived and shepherded by Professors M Ramsay, J G R Kromberg, A Krause and H Soodyall, all of whom have worked with Professor Jenkins for many decades. They have solicited articles on a wide range of human genetics topics from colleagues, collaborators and ex-students who have been associated with him, in the course of their careers. These articles, which reflect Professor Jenkins' wide range of interests, have been arranged into sections relating to medical genetics, molecular genetics and psychosocial and ethical issues, although there is some overlap. This festschrift has been sponsored by the Strategic Planning and Allocation of Resources Committee (SPARC) Fund (in line with the Wits 2010 Strategic Plan) of the University of the Witwatersrand and it serves as a tribute to the tremendous contribution of an indefatigable academic. As one of his previous staff members stated, in a note written for his 80th birthday celebration: 'his endlessly questioning mind, tireless energy, enthusiasm and concern about morality and ethics, not only pertaining to medicine, but to the world at large, made him an inspiring role model for all' (Dr Margot de Saxe, 2012). Professor Jenkins has left the university, and all those who worked with him, with the legacy of inspiration to pursue rigorous research, to question our actions and behaviour, and to treat our fellow humans with respect and dignity.

\section{Jennifer G R Kromberg \\ Michele Ramsay \\ Amanda Krause \\ Himla Soodyall \\ Division of Human Genetics, School of Pathology, Faculty of Health \\ Sciences, University of the Witwatersrand, and National Health Laboratory Service, Johannesburg, South Africa}

S Afr Med J 2013;103(12 Suppl 1):956. DOI:10.7196/SAMJ.7627 